\title{
ORANG KHMER DI JAWA PADA MASA HINDU-BUDDHA (ABAD KE-9--15 MASEHI): EKSISTENSINYA DIPANDANG DARI TEORI DIASPORA
}

\section{KHMER PEOPLE IN JAVA DURING THE HINDU-BUDDHIST PERIOD $\left(9^{T H}-15^{T H}\right.$ CENTURY): THEIR EXISTENCE BASED ON THE DIASPORA THEORY}

\author{
Muhamad Alnoza \\ Alumni Program Studi Arkeologi, Fakultas IImu Pengetahuan Budaya, Universitas Indonesia, \\ JI. Selo Soemardjan, Kampus UI, Depok, Jawa Barat, Indonesia; posel: muhamadalnoza@gmail.com
}

\begin{abstract}
Abstrak. Orang asing di Jawa telah diketahui keberadaannya melalui penyebutan wargga kilalan di prasasti. Prasasti pada masa Airlangga hingga Majapahit dengan gamblang menyebutkan keberadaan orang-orang asing yang dalam hal ini pada konteks penarikan pajak terhadap orang-orang asing tersebut. Salah satu bangsa asing yang mendiami Jawa pada masa Jawa Kuno adalah orang Khmer. Keunikan kasus bermukimnya orang Khmer di Jawa disebutkan pula dalam sumber epigrafi Khmer. Dalam prasasti-prasasti Khmer disebutkan fenomena pemukiman orang Khmer di Jawa, dan diberitakan pula bahwa salah satu raja Khmer pernah menetap di Jawa selama beberapa tahun. Kajian ini berusaha untuk menjawab permasalahan dinamika pendudukan orang Khmer di Jawa. Tujuan penelitian ini adalah untuk mengetahui kedudukan kasus menetapnya orang Khmer di Jawa sebagai suatu fenomena diaspora atau bukan. Tahapan penelitian dilakukan dengan pengumpulan data, analisis, dan interpretasi, dengan data utama berupa prasasti. Kajian ini menghasilkan pemahaman mengenai dinamika motivasi perpindahan tempat bermukim orang Khmer ke Jawa, letak daerah bermukim orang Khmer di Jawa, dan bentuk interaksi orang Khmer dengan orang Jawa. Meskipun demikian, belum ada bukti-bukti yang menguatkan fenomena tersebut sebagai suatu diaspora.
\end{abstract}

Kata kunci: Wargga kilalan, Jawa, Prasasti, Khmer, Diaspora

\begin{abstract}
The presence of foreigners in Java is known from references to 'wargga kilalan' in inscriptions. Inscriptions issued from the Airlangga to Majapahit period clearly mentioned the existence of foreigners, particularly regarding the tax collection of foreigners. One of the foreign communities that resided in Java during the ancient Javanese period was the Khmer people. Such phenomenon is recorded also in inscriptions found in Cambodia, including a Khmer king who spent several years in Java. This study seeks to clarify the dynamics of the relationship of the Khmer residents with the Javanese population and to determine whether this can be considered as an example of a diasporic phenomenon. The steps of the research included data collection, analysis, and interpretation, with inscriptions as the main data. This study yielded an understanding of the motivation for the Khmer migration to Java, the location of the Khmer settlements in Java, and the nature of the interaction between the Khmer and the Javanese. However, there has been no evidence that supported such a phenomenon as a diaspora.
\end{abstract}

Keywords: Wargga kilalan, Java, Inscription, Khmer, Diaspora

\section{PENDAHULUAN}

Kedudukan Asia Tenggara dalam perkembangan sejarah menjadi penting, terutama terkait dengan jalur perdagangan. Letaknya yang berada di antara dua samudra (Hindia dan Pasifik) menyebabkan daerah ini menjadi wilayah lalu lintas perdagangan antara dunia timur (Cina) dan barat (India, Timur Tengah, dan Eropa). Laju perdagangan antarbangsa yang melintasi Asia Tenggara ini sedikit banyak memberikan pengaruh terhadap perkembangan kebudayaan setempat. Kebudayaan India dan Cina pada awal masehi menempati posisi dominan sebagai trend center budaya di Asia Tenggara (Lombard 2005).

Nusantara merupakan sebagian dari Asia Tenggara yang telah lama mendapat sentuhan dari kebudayaan India dan kebudayaan Cina. Kebudayaan India bagi orang Nusantara dan Asia Tenggara secara umum digunakan sebagai legitimasi penguasa setempat. Orang India kuno pada masa awal sejarah justru memandang bangsa Nusantara sebagai rekanan dagang serta pelaut yang handal (Smith 1999). Orang India kemudian merekam eksistensi masyarakat Nusantara melalui beberapa epos keagamaannya, seperti 
Ramayana, Jatakamala, dan Mahanidesa. Wilayah Nusantara dalam penggambaran orang India merupakan wilayah seberang lautan yang tidak terjangkau di sebelah timur India (Munandar 2017).

Pandangan Cina terhadap Nusantara agaknya berlainan dengan India. Cina menganggap negara-negara di daerah Nan Hai (laut selatan) atau Asia Tenggara sebagai tempat tinggal orang-orang barbar. Cina dalam hal ini memosisikan dirinya sebagai Zhongguo (negara tengah) yang dapat diartikan pula sebagai pusat peradaban dunia. Kelebihan yang dimiliki oleh orang Nan Yang adalah komoditas dagang mereka yang melimpah dan seringkali tidak dimiliki oleh orang Cina sendiri. Penggambaran akan perspektif tersebut dapat ditemukan dalam kronik-kronik Cina. Kronik Cina yang merekam peradaban Asia Tenggara dapat ditemui dalam catatan sejarah Dinasti Liu Song dan Dinasti Liang pada abad ke-5--6 M (Groeneveldt 2018).

Masyarakat Nusantara sendiri pada dasarnya memberi keterangan pula mengenai ramainya orang asing yang singgah ke wilayah mereka, salah satu yang memberi keterangan terbanyak terdapat di Jawa. Bukti kontak pertama masyarakat asing di Jawa, khususnya dari India dapat diketahui melalui prasasti-prasasti bercorak kebudayaan India di Jawa Barat. Penggunaan aksara Pallawa dan bahasa Sanskerta pada prasasti di Kerajaan Tarumanagara menjadi bukti paling awal pengaruh budaya atau paling tidak kontak asing pertama di Jawa (Santiko 2001). Masyarakat pada masa Jawa Kuno pada masa selanjutnya makin jelas memberi keterangan akan kontak asing tersebut. Prasasti Kelurak (704 Çaka (S) atau $782 \mathrm{M}$ ) merupakan bukti jelas sekaligus yang paling awal dalam menyebutkan adanya kontak masyarakat Jawa dengan orang asing. Prasasti tersebut menyebutkan kedatangan seorang pendeta bernama Kumaragosha dari Gaudidwipa (Benggala atau Bangladesh modern) yang datang ke Jawa (Poesponegoro dan Notosusanto 2010).

Bukti lain yang memberi banyak informasi mengenai kontak masyarakat lokal dengan orang asing dapat ditemui pada prasasti-prasasti dari masa Raja Airlangga. Prasasti yang dikeluarkan oleh Airlangga beberapa di antaranya menyebutkan perihal nama wargga kilalan. Golongan ini merupakan sekumpulan orang yang diwajibkan untuk membayar pajak karena keahliannya dalam profesi atau statusnya sebagai warga asing. Wargga kilalan juga seringkali disebutkan berdasarkan bangsa atau etnisitas si wajib pajak, misalnya klin (bangsa Tamil dari India), āryyā (bangsa Arya dari India), sińhala (bangsa dari Sri Lanka), pañdikira (bangsa dari India), dravida (bangsa dari India Selatan), campa (bangsa Cham dari Vietnam Selatan), rĕmĕn (bangsa Mon dari Myanmar) dan kmir (bangsa Khmer dari Kamboja). Nama-nama bangsa ini pada dasarnya memberikan keterangan bahwa ada beberapa bangsa dari luar Nusantara yang menetap di Jawa untuk beberapa waktu, mengingat tradisi penyebutan wargga kilalan ini terus dilanjutkan hingga pada masa Majapahit (Susanti 2017).

Penyebutan wargga kilalan sebagai bukti kontak masyarakat asing di Nusantara dalam kajian arkeologi pada dasarnya telah dilakukan oleh beberapa orang. Lien Dwiari Ratnawati (1995) merupakan salah satu orang yang dengan jelas membahas perihal kedudukan orang asing di Jawa dalam tulisannya yang berjudul "Catatan tentang adanya 'orang asing' pada masa Jawa Kuno menurut data prasasti'. Ratnawati dalam tulisan tersebut berusaha untuk menjawab permasalahan mengenai latar belakang keberadaan orang asing di Jawa serta peranannya.

Penelitian selanjutnya yang secara menyeluruh membahas perihal orang asing di Jawa dilakukan oleh Nufus (2018). Nufus dalam skripsinya yang berjudul "Orang-orang asing di Jawa: berdasarkan data prasasti abad ke-11 - 15 Masehi" membahas secara menyeluruh perihal sosok, motif kedatangan, dan pengaturan orang asing pada masa Jawa Kuno.

Penelitian terdahulu pada dasarnya belum berfokus pada tinjauan terhadap satu bangsa tertentu yang berdomisili di Jawa. Kajian ini perlu dilakukan karena tiap-tiap bangsa memiliki pengalaman sejarah serta pandangan sendiri-sendiri terhadap orang Jawa. Bangsa yang dapat diketahui rekam jejak sejarah kontak dengan orang Jawa salah satunya adalah bangsa Khmer.

Bukti kontak antara bangsa Khmer dan Jawa sudah ada sejak masa kekuasaan Dinasti Sailendra dan Yasodharapura di Kamboja. Bukti keberadaan orang Angkor di Jawa dapat diketahui melalui Prasasti Wurudu Kidul yang berangka tahun $844 \mathrm{~S}$ atau $922 \mathrm{M}$ (Boechari 2012a). Bukti hubungan kedua kerajaan tersebut juga muncul dari sumber tertulis Khmer bernama Prasasti Satok Kok Thom (Sdok Kok Thom) yang dikeluarkan 
pada abad ke-11 M. Berita dari dunia Arab menyebutkan bahwa raja Khmer telah dipenggal oleh raja dari Zabaj (Jawa?) (Coedes 2017).

Hubungan diplomasi antara Jawa dan Khmer yang berlangsung hampir separuh masa Klasik di Indonesia ini pada dasarnya juga berkaitan dengan eksistensi orang Khmer di Jawa. Hal ini terbukti dengan dimasukannya orang Khmer ke dalam golongan wargga kilalan yang disebut kmir atau kismira. Pemahaman mendalam akan hubungan diplomasi kedua kerajaan yang terus berlanjut dari satu dinasti ke dinasti yang baru memungkinkan adanya dinamika kependudukan orang Khmer di Jawa. Pembahasan mengenai hal tersebut dapat diperdalam dengan teori diaspora, khususnya kepentingannya dalam kajian arkeologi.

Kata diaspora berasal dari dua suku kata bahasa Yunani, yaitu dia (di antara) dan speiren (menebar benih). Kata ini awalnya digunakan sebagai peristilahan dalam menyebut peristiwa eksodus orang Yahudi. Diskursus mengenai diaspora dalam arkeologi awalnya berkaitan dengan relokasi kebudayaan yang terjadi pada masa kolonialisasi Afrika oleh bangsa Eropa ke Benua Amerika. Kajian diaspora dalam arkeologi kemudian lebih dikembangkan sebagai cara untuk mengetahui fenomena perpindahan kependudukan kuno (Braziel dan Mannur 2003). Kajian mengenai diaspora juga nantinya dapat menjelaskan perihal adanya suatu lokalitas tertentu pada suatu komunitas kebudayaan yang sama sekali berbeda. Hal ini karena pembahasan soal diaspora juga turut menghadirkan konsep mengenai identitas kampung halaman (homeland identity) yang terus dilanjutkan oleh orang-orang yang berdiaspora tersebut (Lilley 2007). Abner Cohen (1971) membagi diaspora berdasarkan latar belakang terjadinya diaspora sebagai berikut, victim diaspora (diaspora yang terjadi karena paksaan), labor diaspora (diaspora yang terjadi karena adanya lapangan kerja diluar tanah air), imperial diaspora (diaspora akibat penaklukan), trade diaspora (diaspora karena kegiatan perdagangan) dan deterritorialized diaspora.

Berdasarkan pemaparan mengenai diaspora tersebut, kajian terhadap pendudukan orang Khmer di Jawa perlu dipandang sebagai suatu fenomena diaspora kendati terdapat beberapa pendekatan dalam memahami kedatangan orang Khmer di Jawa. Kajian diaspora menjadi salah satu pendekatan dalam keilmuan arkeologi yang secara kompleks memahami pelbagai aspek dalam perpindahan suatu massa dari tempat asal ke tempat asing yang baru. Orang Khmer dalam sejarah juga tentu tidak hanya tersebar di Jawa, tetapi juga di beberapa tempat lain, utamanya di beberapa negara di Asia Tenggara. Peneliti lain seperti Max dan Khleangdengan (2013) kajiannya mengenai migrasi orang Khmer ke Thailand pada abad ke-20 M, serta McHale (2013) dengan kajiannya mengenai konflik orang Khmer yang hidup di Vietnam abad ke-18 M, tentu menjadi suatu bukti bahwa orang Khmer telah melakukan diaspora ke beberapa tempat di Asia Tenggara dari masa ke masa. Urgensi dari kajian ini lebih menitikberatkan pada kemungkinan adanya diaspora Khmer di masa yang lebih tua, yaitu antara abad ke-9 dan ke-15 M.

Masalah yang diangkat dalam penelitian ini dengan demikian adalah bagaimana dinamika pendudukan komunitas Khmer di Jawa? Dalam hal ini meliputi letak domisili orang Khmer di Jawa, mata pencahariannya, jumlah penduduk, kehidupan sosial, dan lain sebagainya. Permasalahan yang diangkat dalam penelitian ini bertujuan untuk mengetahui eksistensi pendudukan komunitas Khmer di Jawa sebagai suatu fenomena diaspora atau bukan, mengingat adanya fenomena diaspora orang Khmer di beberapa tempat di Asia Tenggara.

\section{METODE}

Tinjauan mengenai pendudukan komunitas Khmer di Jawa dalam hal ini terdiri atas tiga rangkaian tahapan metode penelitian arkeologi, yaitu pengumpulan data, analisis dan interpretasi (Gibbon 2013). Data yang perlu dikumpulkan dalam penelitian ini adalah berupa sumber data tertulis yang berasal baik dari Jawa maupun dari Khmer. Studi kepustakaan termasuk ke dalam bagian proses pengumpulan data ini. Adapun sumber data yang digunakan sebagai landasan penelitian ini adalah beberapa alih aksara dan alih bahasa dari prasasti-prasasti pada masa Jawa Kuno (abad ke-9 -15 M) yang menyebutkan perihal keberadaan orang Khmer. Data yang telah terkumpul kemudian dianalisis untuk mengurai beberapa gejala yang muncul dari data yang terkumpul. Hasil analisis selanjutnya ditafsirkan melalui analogi kesejarahan (perbandingan gejala pada data arkeologis dengan data sejarah pendukung) yang dalam hal ini dilakukan dengan membandingkan fenomena yang termuat pada data tertulis terhadap perjalanan sejarah kedua negara. 


\section{HASIL DAN PEMBAHASAN}

\section{Sumber-Sumber Tertulis}

\section{Prasasti Sdok Kok Thom}

Prasasti Sdok Kok Thom ditemukan pada suatu bangunan suci di Kamboja sekarang. Angka tahun yang tertera pada prasasti tersebut adalah 974 S (1052 M). Prasasti tersebut kendati berangka tahun abad ke-11 M, tetapi turut pula memuat informasi kesejarahan dari abad ke-9 M. Informasi yang memuat perihal hubungan Jawa dan Khmer justru berasal dari abad ke-9 (802 M), yaitu ketika seorang pangeran dari Jawa bernama Jayawarman II datang ke Khmer dan mendirikan beberapa kota yang di antaranya bernama Indrapura. Jayawarman II kemudian mendeklarasikan diri sebagai Raja Khmer yang merdeka dari kedaulatan Jawa dengan mengangkat diri sebagai seorang devaraja (Munandar 2014).

Nama Jawa dalam Prasasti Sdok Kok Thom sendiri ditafsirkan secara berbeda-beda oleh beberapa peneliti. Griffiths (2013) sebagai salah satu orang yang meneliti nama Jawa pada Prasasti Sdok Kok Thom berpendapat bahwa nama Jawa pada prasasti tersebut dapat disamakan dengan nama Pulau Jawa yang dikenal sampai sekarang. Pendapat tersebut berdasarkan studinya terhadap tradisi penyebutan nama Jawa dari data epigrafi yang tersedia, baik di Khmer, Jawa maupun Champa. Kata Jawa dalam Prasasti Sdok Kok Thom merujuk pada suatu bangsa asing, sedangkan kata Javadvipa merujuk pada suatu endonim (nama lokal).

Coedes (2017) berpendapat bahwa klaim Jayawarman II sebagai raja di Khmer merupakan efek dari melemahnya Dinasti Sailendra di Jawa. Jayawarman II sebagaimana yang disebutkan pula dalam prasasti tersebut berusaha mengeklaim diri sebagai seorang cakravartin ${ }^{1}$ (pelindung dunia) serta mendirikan ibu kotanya di atas Gunung Mahendra (Phnum Kulen). Klaim diri sebagai cakravartin adalah upaya Jayawarman II dalam menyaingi gelar "maharaja" dari raja-raja Sailendra. Penempatan ibu kota di atas gunung dapat diasumsikan secara harfiah sebagai cara Jayawarman II dalam membebaskan serta menyetarakan diri dengan para penguasa gunung di Jawa (kata Sailendra sendiri artinya para penguasa gunung). Seluruh klaim ini kemudian dirangkum dalam suatu upacara terhadap pengultusan bagi sang raja, melalui pengukuhan lingga gaib.

Informasi penting yang agaknya perlu diperhatikan dalam prasasti ini mengenai hubungan Jawa dan Khmer terkandung dalam tiga poin berikut,

- $\quad$ Orang Khmer dan Jawa saling mengenal pada abad ke-9 M atau paling tidak akhir abad ke-8 M;

- Hubungan Jawa dan Khmer dulunya tidak setara, dengan posisi Jawa berhasil menduduki negeri Khmer, walaupun kemudian Khmer berhasil memerdekakan diri;

- Jayawarman II pernah berdomisili di Jawa, dan nenek moyangnya diketahui berasal dari Khmer.

\section{Prasasti Wurudu Kidul A dan B}

Prasasti Wurudu Kidul (berangka tahun $844 \mathrm{~S}$ atau $922 \mathrm{M}$ ) merupakan prasasti lempengan tembaga berukuran 27 × $23 \mathrm{~cm}$, dan sekarang disimpan di Museum Nasional di Jakarta dengan nomor inventaris E.63. Prasasti tersebut dibaca pertama kali oleh Willem F. Stutterheim, dilanjutkan oleh Louis Charles Damais, dan yang terakhir oleh Boechari. Prasasti Wurudu Kidul terdiri atas satu lempeng dengan dua sisi. Bagian depan (recto) atau bagian A terdiri atas 16 baris tulisan, sedangkan bagian belakang (verso) atau bagian B terdiri atas 19 baris tulisan. Lempengan tembaga tersebut ditulis dengan bahasa dan aksara Jawa Kuno (Proyek Pengembangan Museum Nasional 1986). Prasasti ini tidak menyebut perihal raja yang memerintah saat itu, tetapi peristiwa dalam prasasti ini mungkin sekali terjadi pada masa pemerintahan Dyah Tlodhong atau Dyah Wawa apabila dikaitkan dengan prasasti lain yang sezaman (Damais 1955).

\footnotetext{
1 Suatu konsep dalam ajaran Hindu dan Buddha mengenai raja sebagai perwujudan dewa yang melindungi dunia. Jayawarman II dalam prasastinya disebut sebagai "kamrater jagat ta rāja" (raja penguasa semesta) (Kulke 1978) 
Prasasti Wurudu Kidul merupakan prasasti jayapattra (keputusan pengadilan tentang kewarganegaraan atau utang-piutang) yang ditujukan bagi Sań Dhanadī. Individu tersebut sempat disangsikan etnisitasnya sebagai warga pribumi dan disangka sebagai seseorang dari etnis Khmer. Tuduhan tersebut menyebabkan Sań Dhanadī ditagih pajaknya karena dianggap masuk ke dalam wargga kilalan. Sań Dhanadī yang menyangkal hal tersebut, kemudian diinvestigasi oleh pemungut pajak dengan cara menanyai para tetangganya, jika nenek moyang Sań Dhanadī merupakan orang Jawa atau orang Khmer. Hasil investigasi tersebut menunjukkan bahwa San் Dhanadī bukanlah orang Khmer, melainkan orang Jawa asli. Keterangan ini didasarkan pada penuturan warga Desa Grih, Kahuripan dan Panińlaran yang menyebutkan bahwa nenek moyang Sań Dhanadī bukanlah orang Khmer karena tetap menjalankan adat istiadat Jawa. Sañ Dhanadī pun dibebaskan dari pajak sehingga diberikanlah surat jayapattra tersebut (Boechari 2012a).

Prasasti Wurudu Kidul secara tersirat menyediakan informasi paling awal mengenai penetapan orang asing, dalam hal ini orang Khmer, ke dalam golongan wargga kilalan. Prasasti ini juga secara tersirat memberi keterangan bahwa orang Khmer telah menetap di Jawa (khususnya Jawa Tengah) pada abad ke-10 M, terlebih mungkin juga bisa lebih lama dari itu. Asumsi ini muncul dari adanya investigasi terhadap nenek moyang San் Dhanadī yang dikira orang Khmer sehingga bisa dikatakan bahwa orang Jawa saat itu seakan memang sudah mengenal lama masyarakat Khmer yang menetap di Jawa. Orang Khmer di Jawa dalam prasasti ini juga digambarkan masih terikat dengan adat istiadatnya. Hal tersebut merujuk pada sikap Sań Dhanadī yang bagi orang Jawa atau pejabat setempat tidak menjalankan identitas sebagai seorang Khmer atau singkatnya orang Jawa pada masa itu bisa membedakan individu yang beridentitas Khmer dan lokal.

\section{Prasasti-prasasti pada Masa Airlangga dan Setelahnya yang Menyebut Perihal Orang Khmer}

Prasasti pada masa Airlangga yang menyebut perihal keberadaan orang Khmer di Jawa, antara lain Prasasti Cane dan Prasasti Patakan. Kedua prasasti tersebut merupakan prasasti batu yang ditulis dalam bahasa dan aksara Jawa Kuno. Prasasti Cane berangka tahun 943 S atau 1021 M, sedangkan Prasasti Patakan tidak berangka tahun. Kedua prasasti Airlangga ini sama-sama ditemukan di daerah Surabaya (Brandes 1913).

Prasasti Cane secara umum berisi tentang penganugerahan wilayah sima oleh Raja Airlangga kepada warga Desa Cane yang wilayahnya masuk ke dalam tinghal pinghay. Raja Airlangga memberi anugrah tersebut karena jasa masyarakat Desa Cane yang dengan rela hati menjadi benteng di kubu barat Airlangga. Desa ini diasumsikan sebagai wilayah pertahanan Airlangga dari Haji Wura Wari yang datang dari barat. Prasasti ini turut pula menyebutkan pelbagai nama wargga kilalan yang ada di desa tersebut, yang satu di antaranya adalah orang Khmer (Nufus 2018; N. Susanti 2010; Poesponegoro dan Notosusanto 2010).

Prasasti Patakan mungkin sekali juga berasal dari $943 \mathrm{~S}$, kendati memang angka tahun pada prasasti sudah aus dan sulit dibaca. Isi prasasti ini secara umum adalah penetapan Desa Patakan sebagai sima karena di wilayah desa tersebut terdapat bangunan suci Sang Hyang Patahunan. Wilayah desa ini juga, sama seperti Prasasti Cane, juga ditinggali oleh wargga kilalan yang salah satunya adalah orang Khmer (Susanti 2010; Nufus 2018).

Prasasti Garaman merupakan satu-satunya prasasti dari masa pascapembelahan kerajaan oleh Airlangga yang menyebut soal orang Khmer. Prasasti Garaman pertama kali ditemukan pada tahun 1985 di Desa Widang, perbatasan Kabupaten Tuban dan Lamongan. Secara keseluruhan Prasasti Garaman terdiri atas empat lempengan tembaga yang ditulisi dengan menggunakan aksara dan bahasa Jawa Kuno. Angka tahun yang tertera di prasasti ini adalah 975 S atau $1053 \mathrm{M}$, yang dalam hal ini sezaman dengan masa Sri Maharaja Rakai Halu Mapanji Garasakan, sebagaimana yang tertera pula pada prasasti tersebut. Prasasti ini berisi perihal penetapan daerah sima oleh Mapanji Garasakan di Desa Garaman karena jasa warga desa tersebut dalam melaporkan akan adanya posisi musuh (Boechari 2012b). Prasasti Garaman menjadi salah satu bukti dari perkembangan perniagaan dan transportasi air pada masa Jawa Kuno karena keterkaitannya dengan Pelabuhan Kambang Putih (Tuban) (Prihatmoko 2014). Serupa dengan prasasti-prasasti masa Airlangga, informasi mengenai orang Khmer di prasasti ini terletak di bagian penyebutan wargga kilalan. 


\section{Prasasti-prasasti pada Masa Majapahit yang menyebut Perihal Orang Khmer}

Prasasti-prasasti pada masa Majapahit yang melampirkan keterangan mengenai keberadaan orang Khmer di Jawa dapat dibagi menjadi dua, yaitu prasasti yang benar-benar dikeluarkan oleh raja-raja Majapahit dan prasasti tinulad atau yang ditulis ulang pada masa Majapahit. Prasasti Majapahit yang menyinggung orang Khmer adalah Prasasti Balawi dan Prasasti Warunggahan. Prasasti tinulad pada masa Majapahit yang menyebutkan keberadaan orang Khmer adalah Prasasti Kuti dan Prasasti Kaladi.

Prasasti Balawi merupakan batu yang ditemukan di daerah Trowulan, Mojokerto, Jawa Timur. Isi prasasti ditulis menggunakan bahasa dan aksara Jawa Kuno. Prasasti tersebut sekarang disimpan di Museum Nasional di Jakarta, dengan nomor inventaris E. 80 a-f. Prasasti Balawi berangka tahun 1277 S atau 1305 M. Prasasti tersebut dikeluarkan oleh raja Majapahit pertama, yaitu Raja Kertarajasa Jaya Wisnuwardhana. Isi dari prasasti ini menyinggung pada penetapan Desa Balawi oleh sang raja sebagai sima. Penetapan Desa Balawi sebenarnya sudah pernah dilakukan oleh raja sebelumnya, tetapi dulu penetapan ini tidak disampaikan dalam bentuk prasasti. Sang Wirapati kemudian mengajukan pengeluaran prasasti kepada Raja Kertarajasa dan permohonan itu pun dikabulkan oleh sang raja. Adapun penyebutan orang Khmer pada prasasti ini dapat ditemukan pada daftar wargga kilalan yang menduduki wilayah tersebut (Proyek Pengembangan Museum Nasional 1986).

Prasasti Warunggahan bisa dikatakan data prasasti terbaru dari masa Majapahit yang menyebut perihal orang Khmer. Prasasti tersebut ditemukan tahun 2018 di Dusun Trowulan, Desa Bektiharjo, Kecamatan Semanding, Kabupaten Tuban, Jawa Timur. Prasasti Warunggahan ditulis pada 14 lempeng tembaga. Prasasti ditulis dalam bahasa dan aksara Jawa Kuno. Angka tahun yang tertera pada prasasti adalah 1227 S atau 1305 M, serta dikeluarkan oleh Sri Maharaja Narrarya Sanggramawijaya (Kertarajasa) dari Majapahit. Isi Prasasti Warunggahan berkaitan dengan penetapan daerah sima di Desa Warunggahan, karena prasasti sima yang sebelumnya dari desa ini telah hilang. Permintaan pengeluaran ulang prasasti sima atas Desa Warunggahan dilakukan oleh Paduka Mpungku Sri Buddhaketu (Sambodo 2018). Penyebutan orang Khmer dalam prasasti ini pun serupa dengan Prasasti Balawi, yaitu pada bagian daftar wargga kilalan.

Prasasti Kuti merupakan prasasti pada masa Klasik Tua (abad ke-8--10 M) yang ditulis ulang pada masa Majapahit. Prasasti ini ditemukan pertama kali di Desa Joho, Sidoarjo, Jawa Timur. Prasasti ini berbentuk lempengan logam dan ditulis dengan bahasa serta aksara Jawa Kuno. Angka tahun yang tertera pada prasasti adalah $762 \mathrm{~S}$ atau $840 \mathrm{M}$. Putusan pengeluaran prasasti dikeluarkan oleh Sri Maharaja Sri Lokapala Hariwangso tungga dewa nama Raja Bhiseka. Isi dari prasasti ini menyebutkan perihal penetapan sima atas tanah Waharu Kuti (Proyek Pengembangan Museum Nasional 1986). Penyebutan orang Khmer dalam prasasti termaktub pada daftar wargga kilalan yang menetap di desa ini.

Orang Khmer sebagai wargga kilalan turut pula disebut pada Prasasti Kaladi. Prasasti tersebut ditemukan di daerah Gunung Penanggungan, Jawa Timur. Prasasti Kaladi ditulis dalam aksara dan bahasa Jawa Kuno pada lempengan logam. Prasasti tinulad tersebut berangka tahun 831 S/909 M. Titah pada prasasti dikeluarkan oleh Raja Dyah Balitung. Isi prasasti ini berkaitan dengan penetapan sima dari tiga desa, yaitu Kaladi, Gayam dan Pyapya. Alasan dari penetapan ketiga desa tersebut adalah keberadaan hutan yang rawan akan terjadinya kejahatan sehingga diharapkan hutan tersebut kemudian dapat dimanfaatkan sebagai sawah (Nufus 2018; Damais 1955; Proyek Pengembangan Museum Nasional 1986).

\section{Pembahasan}

Pembahasan mengenai orang Khmer di Jawa dapat berdasarkan pada hasil analisis berupa peta (Gambar 1) dan tabel (tabel 1). Orang Khmer di Jawa pada masa-masa awal kejayaan Kerajaan Mataram Kuno, belum dapat diketahui wilayah persebarannya. Berdasarkan rujukan pada Prasasti Wurudu Kidul, orang Khmer hanya disebutkan sebagai salah satu golongan dalam kelompok wargga kilalan, itu pun tidak mengacu pada keberadaan orang Khmer yang tinggal di wilayah Desa Wurudu Kidul. Keterangan mengenai keberadaan orang Khmer di Jawa pada Mataram Kuno justru muncul dari sumber Khmer sendiri. Jayawarman II yang memerintah di Khmer pada abad ke-9 M, seperti yang telah disebutkan di atas, pernah tinggal di Jawa. 
Sampai pada tataran ini, dapat dipahami bahwa keberadaan orang Khmer di Jawa tidak asing sama sekali. Tentu yang perlu diperhatikan kembali di sini adalah keberadaan orang Khmer di Jawa bukan hanya berasal dari golongan saudagar yang berdagang di Jawa, melainkan juga dari golongan ksatria, yang terbukti dengan menetapnya Jayawarman II yang berstatus ksatria di Jawa. Penyebab perpindahan ksatria Khmer ke Jawa dapat ditarik ke belakang pada peristiwa sejarah yang terjadi di Khmer semenjak awal abad ke-8 M. Lawrence Palmer Briggs (1951) menyebutkan bahwa pada akhir abad ke-7 M, Dinasti Pra-Angkor diperintah oleh Raja Jayawarman I. Raja ini memerintah dengan damai, hanya saja pada akhir hayatnya, Jayawarman I tidak menurunkan generasi penerus untuk melanjutkan kekuasaannya. Kekosongan kekuasaan tersebut, sebagaimana yang disebut dalam kronik Cina, menyebabkan Khmer mengalami perpecahan dan konflik internal. Kamboja pada masa itu terbelah menjadi dua, dengan bagian utara disebut sebagai Chen La darat dan bagian selatan disebut sebagai Chen La laut. Konflik ini terus berkembang sampai akhirnya Khmer diserang oleh Dinasti Sailendra; pada konteks ini, terdapat perbedaan pendapat mengenai kerajaan Nusantara yang menyerang Khmer pada abad ke-8 M. Penyerangan terhadap Khmer agaknya menyebabkan destruksi terhadap berbagai monumen penting mereka, termasuk keruntuhan ibu kota. Tentu hal penting pada tataran ini yang perlu disoroti bahwa keadaan politik di Khmer pada abad ke-8 M dan ke-9 M mempengaruhi mobilisasi masyarakat di sana. Jayawarman II bisa dikatakan sebagai contoh dari orang Khmer yang terkena dampak peristiwa politik ini, kendati kedatangan Jayawarman II tidak dapat dijadikan bukti adanya perpindahan masyarakat Khmer ke Jawa. Fakta bahwa Jayawarman II pernah menetap di Jawa, dalam hal ini sebatas bukti mengenai adanya kontak permulaan antara orang Khmer dan orang Jawa.

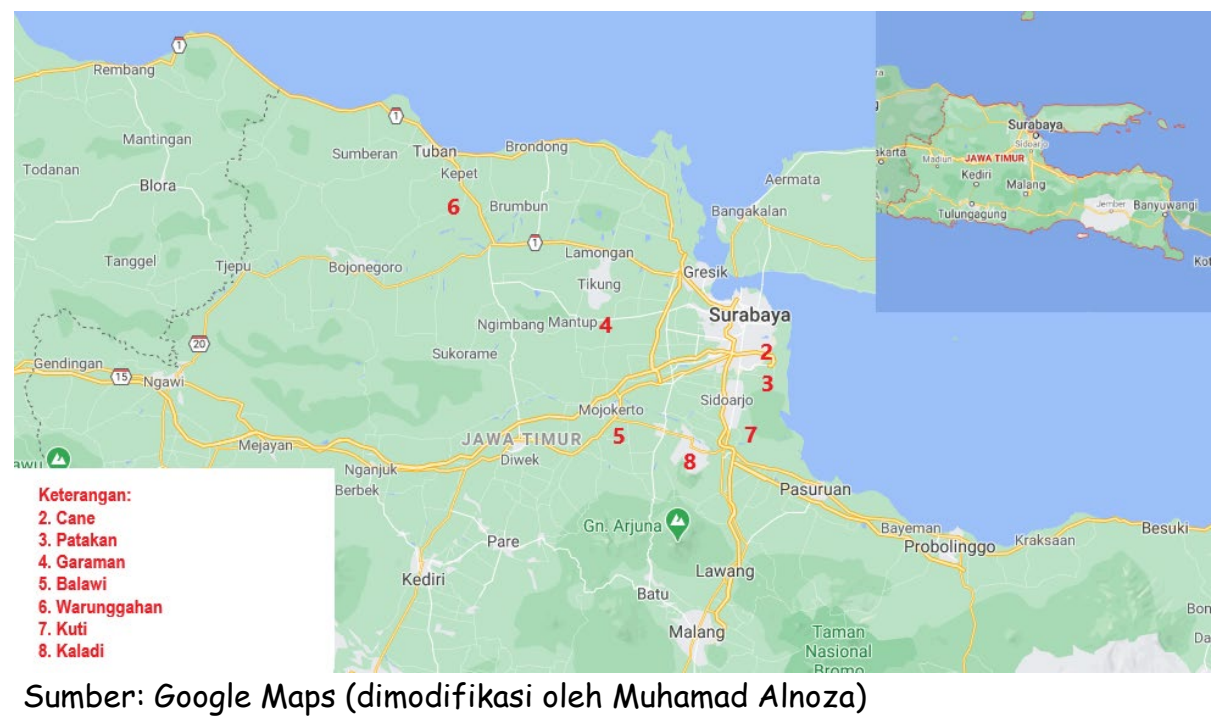

Gambar 1 Persebaran Orang Khmer berdasarkan Persebaran Prasasti yang menyebut Orang Khmer di Jawa Timur

Tabel 1 Tabel Analisis Prasasti Jawa Kuno yang menyebut Orang Khmer

\begin{tabular}{|c|c|c|c|c|c|c|}
\hline No & Nama Prasasti & Angka Tahun & $\begin{array}{c}\text { Tempat } \\
\text { Penemuan }\end{array}$ & $\begin{array}{c}\text { Jenis } \\
\text { Prasasti }\end{array}$ & Tinulad & $\begin{array}{c}\text { Kerajaan yang } \\
\text { Mengeluarkan Prasasti }\end{array}$ \\
\hline 1 & Wurudu Kidul & $922 \mathrm{M}$ & Tidak diketahui & Jayapattra & $X$ & Mataram Kuno \\
\hline 2 & Cane & $1021 \mathrm{M}$ & $\begin{array}{l}\text { Surabaya, } \\
\text { Jawa Timur }\end{array}$ & Sima & $X$ & Medang \\
\hline 3 & Patakan & $1021 \mathrm{M}(?)$ & $\begin{array}{l}\text { Surabaya, } \\
\text { Jawa Timur }\end{array}$ & Sima & $X$ & Medang \\
\hline 4 & Garaman & $1053 \mathrm{M}$ & $\begin{array}{l}\text { Tuban, Jawa } \\
\text { Timur }\end{array}$ & Sima & $X$ & Janggala \\
\hline 5 & Balawi & $1305 \mathrm{M}$ & $\begin{array}{l}\text { Mojokerto, } \\
\text { Jawa Timur }\end{array}$ & Sima & $X$ & Majapahit \\
\hline 6 & Warunggahan & $1305 \mathrm{M}$ & Tuban, Jawa & Sima & $X$ & Majapahit \\
\hline
\end{tabular}


Orang Khmer di Jawa pada Masa Hindu-Buddha (Abad ke-9--15 M): Eksistensinya Dipandang dari Teori Diaspora- Muhamad Alnoza (1-14)

Doi: $10.24832 / n w . v 15 i 1.453$

\begin{tabular}{|c|c|c|c|c|c|c|}
\hline No & Nama Prasasti & Angka Tahun & $\begin{array}{c}\text { Tempat } \\
\text { Penemuan }\end{array}$ & $\begin{array}{c}\text { Jenis } \\
\text { Prasasti }\end{array}$ & Tinulad & $\begin{array}{c}\text { Kerajaan yang } \\
\text { Mengeluarkan Prasasti }\end{array}$ \\
\hline \multicolumn{7}{|c|}{ Timur } \\
\hline 7 & Kuti & $840 \mathrm{M}$ & $\begin{array}{l}\text { Sidoarjo, Jawa } \\
\text { Timur }\end{array}$ & Sima & V & $\begin{array}{l}\text { Mataram Kuno } \\
\text { (Majapahit) }\end{array}$ \\
\hline 8 & Kaladi & $909 \mathrm{M}$ & $\begin{array}{l}\text { Mojokerto, } \\
\text { Jawa Timur }\end{array}$ & Sima & V & $\begin{array}{c}\text { Mataram Kuno } \\
\text { (Majapahit) }\end{array}$ \\
\hline
\end{tabular}

Keterangan: $\mathrm{V}=$ tinulad; $\mathrm{X}=$ bukan tinulad

Sumber: Hasil Penelitian Muhamad Alnoza

Tokoh ini bisa dianggap telah membawa ide-ide yang awalnya tumbuh berkembang di Khmer. Asumsi ini didukung oleh pendapat Briggs (1951) yang mengatakan bahwa praktik pemujaan devaraja dan lingga yang diperkenalkan Jayawarman II di Khmer berasal dari Jawa. Pendapat Briggs dilandasi oleh keterangan Prasasti Dinoyo yang menyebutkan keberadaan monumen bagi Agastya yang merepresentasikan keluarga kerajaan. Praktik devaraja tertua di Jawa juga sedikit banyak terlihat dengan jelas pada klaim Raja Purnawarman sebagai Dewa Wisnu, Indra, dan Surya di Jawa Barat yang masa hidupnya jauh sebelum Jayawarman II hidup (Ras 2001). Tidak berlebihan apabila kemudian Jayawarman II justru telah menyerap ide-ide soal pemujaan devaraja dari Jawa dan kemudian menyempurnakannya di Khmer. Jelasnya dapat diasumsikan bahwa ksatria Khmer telah menyerap kebudayaan Jawa dan mengembangkannya di Khmer.

Pembahasan mengenai penyerapan beberapa unsur kebudayaan Jawa atau Nusantara secara umum ke dalam kebudayaan Khmer pada masa Pra-Angkor (abad ke-7-8 M), pada dasarnya pernah dibahas. Michael Vickery (1998) menyebutkan bahwa orang Khmer pada masa sebelum berdirinya Kerajaan Angkor sedikit banyak menyerap kebudayaan Jawa dari segi kebahasaannya, seperti yang dapat dilihat dari adanya beberapa peminjaman kosakata pada beberapa prasasti di Battambang dan Siem Reap. Uniknya peminjaman kosakata tersebut berkaitan dengan penyebutan satu barang komoditas. Vickery memandang fenomena ini sebagai suatu gejala dari pengaruh linguistik dan ekonomi orang Jawa, walaupun mungkin juga dari orang Cham di Kamboja pada masa Pra-Angkor. Bukti tersebut sedikit banyak menggambarkan bahwasanya orang Jawa atau paling tidak orang Nusantara yang berbahasa Austronesia pernah lalu-lalang datang ke Khmer pada masa sebelum penyerangan Jawa ke Khmer.

Prasasti masa Airlangga menjadi prasasti paling awal yang paling memungkinkan untuk dapat diketahuinya letak permukiman orang Khmer. Letak tempat tinggal orang Khmer tentu dapat ditelisik melalui tempat penemuan prasasti itu sendiri. Apabila mengikuti tempat penemuan prasasti, maka orang Khmer pada masa Airlangga kebanyakan berkumpul di daerah pesisir, seperti Tuban dan Surabaya. Tuban dan Surabaya merupakan pelabuhan besar pada masa Jawa Kuno, sebagaimana digambarkan dalam prasasti. Bukti tertua yang menyebutkan hal ini berasal dari Prasasti Kambang Putih, yang menyatakan bahwa Mapanji Garasakan telah melaksanakan kegiatan perdagangan di Tuban (Kambang Putih) yang dibangun sejak masa kekuasaan Airlangga. Kambang Putih sebagai pelabuhan difungsikan sebagai pelabuhan internasional yang melayani berbagai kapal dagang dari seluruh penjuru dunia. Selain Kambang Putih, terdapat pula pelabuhan Hujung Galuh dari masa Airlangga. Hujung Galuh terletak di hilir Sungai Brantas, yang kemungkinan besar adalah Mojokerto. Hujung Galuh merupakan pelabuhan yang melayani kapal dagang yang berasal dari pulau-pulau di Nusantara (Rahardjo 1994; N. Susanti 2010).

Kesadaran orang Jawa akan adanya pelabuhan sebagai pemangku kebutuhan dagang dengan orang di luar Pulau Jawa agaknya memang baru tergerak pada abad ke-10 M. Betram Johannes Otto Schrieke (2016) bahkan menyebutkan bahwa alasan perpindahan ibu kota Mataram Kuno dari Jawa Tengah ke Jawa Timur karena makin ramainya Jawa Timur sebagai persinggahan para pedagang. Pedagang dari Maluku datang dengan angin timur ke Jawa Timur untuk menukarkan rempah-rempah dengan beras, sedangkan orang-orang dari luar Nusantara datang dengan angin barat untuk menukarkan komoditas mereka (keramik, sutra dan sebagainya) dengan rempah. Intensitas perdagangan ini tumbuh sampai pada puncaknya pada masa pemerintahan Airlangga dan raja-raja sesudahnya.

Perhatian akan perdagangan serta hubungan internasional pada abad ke-11 $\mathrm{M}$ juga rupanya terjadi di Khmer. Raja Suryawarman I yang saat itu memerintah membutuhkan banyak sumber daya untuk membangun monumen-monumen penting dan biaya perang untuk perluasan wilayah, sebagaimana yang telah dicatat 
dalam sejarah bahwa raja ini memang seorang pembangun infrastruktur dan ambisius dalam memperluas wilayah (Coedes 2017). Posisi negara Khmer yang langsung berhadapan dengan Laut Cina Selatan menyebabkan wilayah ini menjadi strategis sebagai jalur perdagangan. Laut Cina Selatan menghubungkan dataran Cina dan Teluk Tonkin di Utara dan wilayah kepulauan Nusantara di selatan. Upaya Khmer untuk membangun koneksi perdagangan menjadi hal yang wajar, karena sifatnya amat esensial dalam membangun negara yang sedang dalam tahap pembangunan besar-besaran. Upaya pembangunan negara menjadi penting, terlebih karena memang posisi Kamboja yang menguntungkan dalam jalur perdagangan (Gambar 2). Kedudukan orang Khmer di Jawa pada abad ke-12 M dengan demikian dapat diasumsikan sebagai hasil pertemuan kepentingan dagang orang Jawa dan Khmer sendiri.

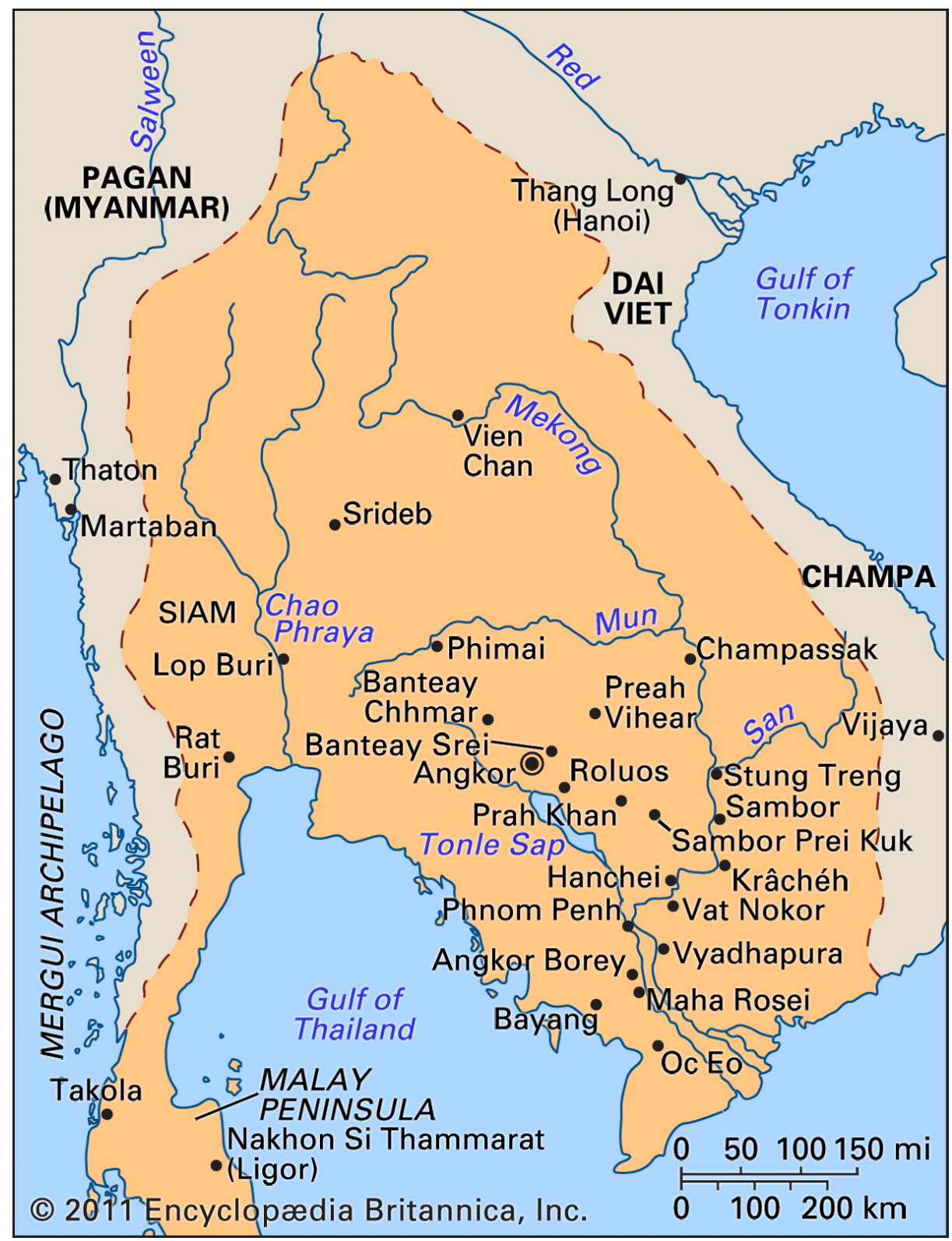

Sumber: https://www.britannica.com/place/Cambodia/The-Khmer-state-Angkor Gambar 2 Wilayah Kerajaan Khmer pada Abad ke-12 M (wilayah berwarna jingga)

Ketika memasuki masa Majapahit, terdapat suatu gejala yang memberikan suatu pola yang berbeda dengan gejala kependudukan orang Khmer di Jawa pada masa kekuasaan Raja Airlangga. Berdasarkan sebaran prasasti yang menyebut perihal wargga kilalan (orang asing), orang Khmer pada masa Majapahit sudah mulai mendiami wilayah pedalaman walaupun sebagian juga tetap tinggal di pesisir (merujuk pada Prasasti Warunggahan). Prasasti Balawi yang ditemukan di Mojokerto mengisyaratkan petunjuk bahwa orang Khmer telah mendiami wilayah pedalaman, bahkan ibu kota Majapahit pada masa itu. 
Gejala yang disampaikan di atas dapat dikaitkan dengan paham politik Majapahit dalam memandang negara-negara rantau di sekitarnya. Munandar (2020) menyebutkan bahwa Majapahit mempunyai suatu cara pandang sendiri terhadap negara-negara di sekitarnya, yang dalam hal ini berakar dari konsep Tri Angga. Konsep Tri Angga adalah konsep mikrokosmos horizontal Majapahit dalam membagi dunia ke dalam tiga hierarki, yaitu uttama, madya dan nista. Penerapan konsep ini sifatnya universal karena dapat diaplikasikan pada struktur tata kota, struktur penataan bangunan (suci ataupun profan), dan termasuk di dalamnya adalah pandangan Majapahit terhadap negara-negara di sekitarnya.

Bukti akan pandangan Majapahit terhadap negara asing serta implementasinya dalam Tri Angga, dapat telusuri dari sumber naskah. Pandangan Majapahit terhadap negara asing (di luar Nusantara) dengan jelas disebutkan dalam Kakawin Nagarakrtagama pupuh 15 bait pertama, yang berbunyi:

\section{"tuhun/tan syańk āyodyapura kimutan darmmānāgarî, marut mamwanrinrajapuranguniwehsińhanaragari, ri campa kambojanyatiyawanamitrekasatatā"}

artinya:

"adapun Syangka, Ayodhyapura, tidak terlupa Darmmanagari, Marutma, serta Rajapura, termasuk Singhanagari, Campa, Kamboja, Yawana, mereka itu adalah teman sederajat” (Pigeaud 1960).

Berdasarkan kutipan tersebut, Munandar (2020) menyebutkan bahwa Majapahit memandang negara di luar Asia Tenggara sebagai wilayah madya. Wilayah ini sifatnya setara dan dianggap potensial untuk diajak bekerja sama dengan Majapahit. Solidaritas antarnegara-negara Asia Tenggara pada masa itu memiliki bentuk yang kurang lebih sama dengan negara-negara Asia Tenggara modern, yang kemudian menjadi unik adalah bahwa Majapahit telah menyadari hal tersebut sejak lama.

Kesadaran akan solidaritas ini kemudian menjadi wajar terjadi pada zaman Majapahit, mengingat masa kelahiran Majapahit juga merupakan masa keganasan Dinasti Mongol Yuan di Cina dalam membentuk hegemoninya di Asia Tenggara. Ketika memasuki awal abad ke-13 M, orang Mongol mampu meluaskan wilayahnya berkali-kali lipat di Asia Tenggara dengan terlebih dahulu menekan orang Thai di wilayah Yunnan, Dinasti Pagan di Burma, bahkan menduduki Vietnam yang pada saat itu dipimpin Kerajaan Dai Viet. Negara-negara Indo-Cina lain, seperti Campa dan Khmer juga berangsur-angsur mendapat gempuran dari armada Dinasti Yuan pada awal abad ke-13 M, walau kemudian dapat dilawan balik oleh kerajaan-kerajaan tersebut. Marco Polo yang datang ke Sumatra pada abad yang sama, bahkan menyebutkan bahwa kerajaan-kerajaan Islam di utara Sumatera juga telah tunduk di bawah kaki Khan besar (Kubilai Khan) (Coedes 2017).

Pendudukan orang Mongol atas wilayah Asia Tenggara agaknya menjadi momok yang besar di negara-negara Asia Tenggara karena nyatanya negara-negara ini saling bahu-membahu dalam menghadapi keganasan Mongol. Bukti asumsi ini terlihat dari gelagat para penguasa kerajaan-kerajaan di Asia Tenggara sebagaimana yang disebutkan oleh Coedes (2017), misalnya Kerajaan Campa yang sampai empat kali memohon jalinan koalisi dengan Dai Viet yang nyatanya adalah pesaing besar kerajaan tersebut di wilayah Vietnam pada masa sebelumnya. Momok ini juga yang kemudian memunculkan memori kolektif kalangan orang Thai yang kerap menyebut orang Mongol sebagai "orang biadab" yang menjajah mereka, sebagaimana tertera pada sumber tertulis pada abad ke-13 $\mathrm{M}$.

Majapahit sebagai penerus Singhasari di Jawa paham betul dengan kondisi Asia Tenggara yang porak-poranda, bahkan sejak masa Singhasari. Upaya menghalau Mongol telah dilakukan sejak masa pemerintahan Krtanegara, yang kemudian menginisiasi perluasan cakrawala mandala. Perluasan cakrawala mandala dilakukan dengan menaklukkan beberapa wilayah atau menjalin persekutuan dengan negara-negara di luar Jawa dalam rangka menggalang kekuatan untuk membendung Mongol. Singhasari pada masa itu diketahui telah menaklukkan Madura, Malayu, Bali, Kalimantan, dan Pahang. Paham cakrawala mandala ini kemudian menjadi embrio bagi konsep Nusantara pada masa Majapahit (Poesponegoro dan Notosusanto 2010). 
Keterbukaan serta solidaritas yang telah lama dipupuk oleh Majapahit ini yang memungkinkan penduduk Khmer untuk tinggal di ibu kota Majapahit. Momok akan satu musuh besar secara tidak langsung telah memperkenankan orang Khmer untuk tinggal di Trowulan. Terlebih lagi, memang Majapahit berhasil dalam menghalau invasi Mongol yang dipimpin oleh Ike Mese dan Gao Xing pada tahun 1293, seperti yang disebutkan oleh Willem Pieter Groeneveldt (2018).

Mengenai prasasti-prasasti tinulad dari masa Majapahit yang disebutkan di atas, perlu dipertimbangkan dua hal dalam mengkaji uraian mengenai orang Khmer pada prasasti tersebut. Pertama, apabila mengikuti pertanggalan dari kedua prasasti tinulad dari masa Majapahit, orang Khmer paling lambat telah menghuni Jawa Timur pada masa pemerintahan Dyah Balitung. Kedua, apabila mengikuti tempat penemuan kedua prasasti, orang Khmer pada masa KlasikTua (abad ke-8--10 M) telah menghuni pedalaman dan pesisir secara sekaligus.

Dua poin informasi yang disampaikan prasasti tinulad ini agaknya tidak sepenuhnya tepat sama sekali karena ada unsur-unsur informasi tersebut yang berlawanan sama sekali dengan fakta-fakta berikut:

- istilah wargga kilalan pada masa Dyah Balitung belum pernah disebut dalam prasasti-prasasti yang ia keluarkan pada masa pemerintahannya;

- walaupun benar Jayawarman II pernah tinggal di Jawa pada abad yang sama dengan Dyah Balitung, tetapi belum pernah ditemukan adanya informasi mengenai letak tempat tinggal Jayawarman II selama di Jawa sehingga sukar memastikan jika memang ada komunitas Khmer di Jawa Timur pada abad ke-9 M;

- konsep wargga kilalan secara samar-samar baru muncul pada zaman antara Dyah Tlodhong dan Dyah Wawa dalam Prasasti Wurudu Kidul yang mungkin sekali ditemukan di Jawa Tengah (terkait dengan bentuk hurufnya yang lebih dekat dengan gaya penulisan Jawa Tengah).

Pembahasan tentang prasasti-prasasti tinulad tersebut pada akhirnya mengantarkan pada suatu interpretasi bahwa penyebutan wargga kilalan pada prasasti tersebut baru benar-benar ditulis pada masa Majapahit. Penulisan wargga kilalan pada prasasti tinulad ini pada akhirnya memang menggambarkan kondisi kependudukan orang Khmer pada masa Majapahit, sebagaimana yang ditunjukkan pada prasasti-prasasti "asli" yang dikeluarkan oleh Majapahit.

Dari panjangnya masa pendudukan orang Khmer di Jawa, sebagaimana yang telah disebutkan di atas, dapatkah pendudukan orang Khmer di Jawa ini disebut sebagai suatu fenomena diaspora? Jawaban akan pertanyaan itu baru didapatkan apabila dilakukan perbandingan antara komposisi dari suatu fenomena diaspora dengan kondisi kependudukan orang Khmer sesuai dari data yang tersedia. Safran (1991) menyebutkan bahwa apabila ada suatu komunitas kebudayaan yang terpisah dari komunitas kebudayaan homogen di sekitarnya akan disebut sebagai diaspora jika terdapat beberapa aspek yang perlu ada dalam tubuh komunitas tersebut, yaitu komunitas tersebut:

- telah terpisah dari wilayah induknya dan menetap di wilayah asing;

- memiliki memori kolektif mengenai nenek moyang mereka atau gambaran tempat mereka berasal;

- meyakini bahwa mereka akan tetap dianggap berbeda oleh masyarakat di tempat mereka merantau

- tetap mengidealkan wilayah asal mereka;

- akan terus mempertahankan solidaritas mereka agar tetap "guyub";

- memiliki upaya untuk selalu terhubung dengan wilayah asal.

Keterangan dalam prasasti dengan amat jelas memperlihatkan bahwa orang Khmer pada abad ke-9-14 M memang telah bermukim terpisah dari induk negaranya di Kamboja. Penyebutan kata wargga dalam mengklasifikasikan orang Khmer pada prasasti menunjukkan bahwa orang Khmer telah menjadi penduduk di Jawa pada periode tersebut. Prasasti juga dengan amat jelas memberikan keterangan mengenai lokasi orang-orang Khmer itu menetap selama di Jawa.

Jayawarman II dapat dianggap sebagai contoh dari orang Khmer yang tetap mempertahankan memorinya soal asal muasal tempat dirinya berasal dan mengidealkan tempat tersebut. Bukti yang menguatkan hal tersebut dapat dilihat pada keputusannya untuk pulang kembali ke Khmer setelah lama tinggal di Jawa. Kepulangan ini juga menandai masih kuatnya pandangan akan kedudukan Khmer sebagai kampung halaman yang ideal karena Jayawarman II memelihara kebudayaan Khmer dengan mengeklaim suatu garis keturunan tradisional Khmer untuk memperkuat kedudukannya sebagai raja di sana. Fenomena ini seakan-akan menggambarkan Jayawarman II sebagai orang yang paham sekali akan kebudayaan dan sejarah Khmer kendati dirinya pernah hidup di Jawa selama beberapa tahun. 
Komunitas Khmer sebagaimana yang terlihat pada data prasasti dan naskah, dibedakan sama sekali dengan penduduk lokal. Pemungutan pajak orang Khmer dalam suatu satuan khusus (dalam hal ini pajak khusus wargga kilalan) menunjukkan bahwa orang Khmer tidak benar-benar melebur dengan masyarakat pribumi Jawa. Terlebih juga dalam Nagarakrtagama, orang Khmer dengan jelas-jelas disebut sebagai "teman sejajar", bukan disebut sebagai warga mandala Majapahit dan sebagainya.

Poin-poin lain yang belum bisa dijawab dalam kajian ini adalah cara orang Khmer untuk terus terhubung dengan wilayah asalnya atau dalam hal ini berusaha untuk memadukan kebudayaan aslinya dengan kebudayaan sekitar. Prasasti tidak pernah dengan jelas pula menyebutkan bentuk solidaritas yang dilakukan oleh orang-orang Khmer di Jawa. Bukti arkeologis di Indonesia yang berkaitan dengan orang Khmer pun tidak banyak jumlahnya karena kebanyakan berpusat di Jawa. Munandar (2018) menyebutkan bahwa pengaruh Khmer dengan jelas dapat terlihat pada beberapa candi masa Majapahit, seperti Candi Pari (Sidoarjo, Jawa Timur; Gambar 3) dan Candi Kesiman Tengah (Mojokerto, Jawa Timur). Pengaruh Khmer di Candi Pari terlihat dari bentuk bangunan yang melebar serta penggunaan relief motif medalion pada ambang pintu candi. Pada Candi Kesiman Tengah, pengaruh Khmer dibuktikan dengan adanya lubang-lubang di bagian panil-panil relief.

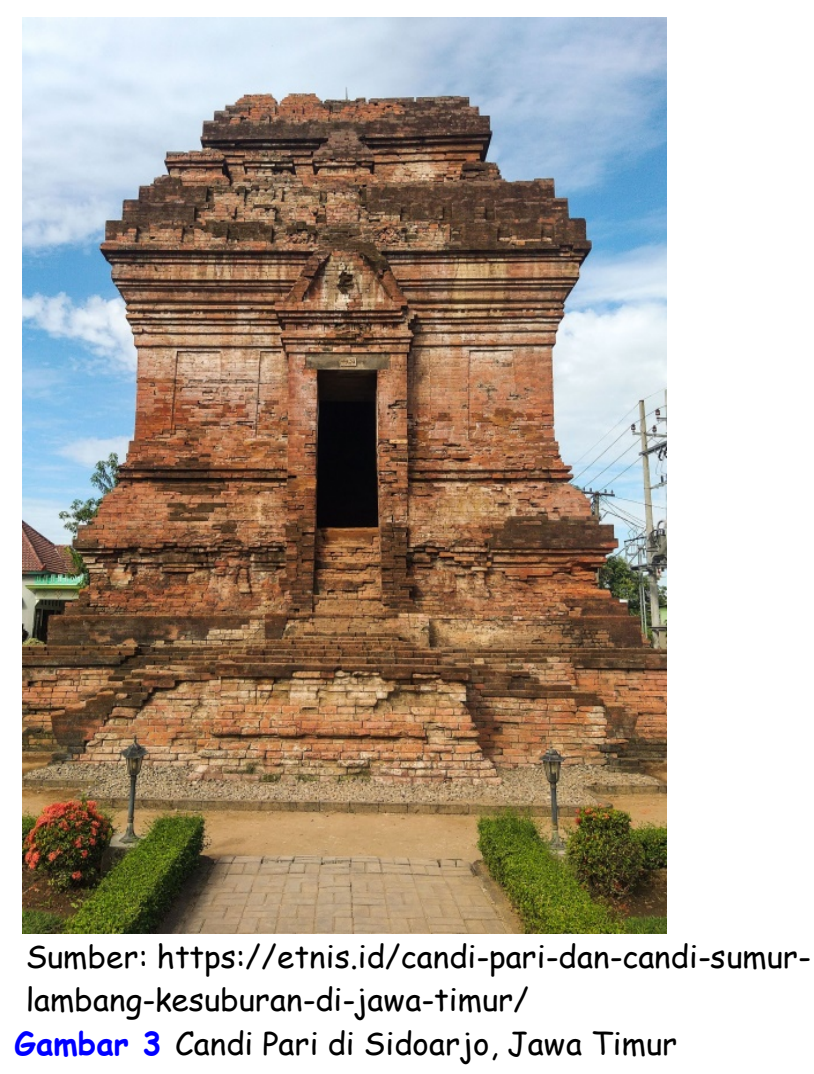

\section{PENUTUP}

Prasasti Jawa Kuno yang berasal dari abad ke-9_14 M telah memberikan informasi mengenai dinamika daerah tempat bermukim dan motivasi perpindahan dan bentuk interaksi terhadap penduduk sekitar dari orang Khmer yang bermukim di Jawa. Dinamika yang terjadi dari masa ke masa disebabkan oleh peristiwa-peristiwa sejarah yang melingkupi proses pendudukan orang Khmer di Jawa. Kebijakan poltik raja-raja Jawa juga besar kecilnya menentukan adanya dinamika kependudukan orang Khmer selama di Jawa.

Orang Khmer lebih detailnya tinggal di Jawa karena perang saudara dan dorongan ekonomi. Pada umumnya orang Khmer yang tinggal di Jawa adalah pedagang walaupun terdapat pula golongan ksatria Khmer yang bermukim di Jawa pada masa Klasik Tua. Orang Khmer di Jawa Timur umumnya tinggal di pesisir, tetapi pada masa Majapahit kemudian tinggal di pedalaman. Postulat tersebut dibuktikan dari sebaran 
temuan prasasti serta bukti arkeologis yang berkaitan dengan orang Khmer. Kedua bukti ini umumnya ditemukan di daerah pesisir, meskipun sebagian juga ditemukan di daerah pedalaman.

Namun demikian, keterangan dalam prasasti juga tidak sepenuhnya memberikan informasi yang lengkap. Informasi mengenai jumlah, perilaku, dan pengelolaan orang Khmer tidak pernah disebutkan dalam prasasti. Sampai saat ini pun belum pernah ditemukan data arkeologis yang signifikan dalam merekonstruksi poin-poin yang tidak disebutkan dalam prasasti mengenai orang-orang Khmer. Pendudukan orang Khmer pada akhirnya belum dapat disebut sebagai fenomena diaspora.

Di sisi yang lain, sejarah pendudukan orang Khmer di Jawa pada akhirnya juga tetap memiliki nilai penting. Bukti prasasti menyebutkan bahwa orang Khmer merupakan bangsa Asia Tenggara daratan pertama yang bermukim di Jawa. Penyerapan ide mengenai dewaraja dari Jawa yang kemudian dikembangkan di Khmer juga dapat disebut sebagai dampak dari bermukimnya orang Khmer di Jawa.

\section{UCAPAN TERIMA KASIH}

Terima kasih saya ucapkan kepada Dian Sulistyowati, M.Hum. yang telah memberikan masukan terhadap penulisan artikel ini. Tidak lupa juga saya ucapkan terima kasih sebesar-besarnya kepada Asri Hayati Nufus, S.Hum. yang telah memberikan saya beberapa data utama dalam menelusuri keberadaan orang asing di Jawa.

\section{DAFTAR PUSTAKA}

Boechari. 2012a. "Jayapattra: Sekelumit Tentang Pelaksanaan Hukum dalam Masyarakat Jawa Kuno." HIm 237-248 dalam Melacak Sejarah Kuno Indonesia Lewat Prasasti. Jakarta: Kepustakaan Populer Gramedia dan EFEO.

Boechari. 2012b. "The Inscription of Garaman Dated 975 Saka New Evidence on Airlangga's Partition of His Kingdom." HIm. 437-452 dalam Melacak Sejarah Kuno Indonesia Lewat Prasasti. Jakarta: Kepustakaan Populer Gramedia dan EFEO.

Brandes, Jan Laurens Andries. 1913. Oud-Javaansche Oorkonden: Negalaten Transcripties. Batavia: Albrecht $\&$ Co.

Braziel, Jana Evans, and Anita Mannur. 2003. "Nation, Migration, Globalization: Points of Contention in Diaspora Studies." HIm. 1-22 dalam Theorizing Diaspora: A Reader, editor ana Evans Braziel and Anita Mannur. Maiden: Blackwell Publishing.

Briggs, Lawrence Palmer. 1951. "The Ancient Khmer Empire." Transactions of the American Philosophical Society 40 (1): 1-295. https://doi.org/10.1016/j.serrev.2008.02.007.

Coedes, George. 2017. Asia Tenggara Masa Hindu-Buddha. Jakarta: Kepustakaan Populer Gramedia dan EFEO.

Cohen, Abner. 1971. "Cultural Strategies in the Organization of Trading Diasporas." HIm. 266-281 dalam L'evolution Du Commerce Africain Dupuis Le XIXe Siecle En Afrique Du l'ouest, edited by Claude Meillassoux, 266-81. Oxford: Oxford University Press.

Damais, L.C. 1955. "Études d'épigraphie Indonésienne: Discussion de La Date Des Incriptions." Bulletin de l'Ecole Française d'Extrême-Orient.

Gibbon, Guy. 2013. Critically Reading the Theory and Methods of Archaeology: An Introductory Guide. Maryland: Rowman \& Littlefield Publishers.

Griffiths, Arlo. 2013. "The Problem of the Ancient Name Java and the Role of Satyavarman in Southeast Asian International Relations Around the Turn of the Ninth Century CE." Archipel 85 (1): 43-81. https://doi.org/10.3406/arch.2013.4384.

Groeneveldt, Willem Pieter. 2018. Nusantara Dalam Catatan Tionghoa. Depok: Komunitas Bambu.

Kulke, Hermann. 1978. Devaraja Cult. New York: Department of Asian Studies Cornell University.

Lilley, lan. 2007. "Diaspora and Identity in Archaeology: Moving beyond the Black Atlantic." HIm. 287-305 dalam A Companion to Social Archaeology, edited by Lyn Meskell and Robert W. Preucel. Oxford: Blackwell Publishing.

Lombard, Denys. 2005. Nusa Jawa: Silang Budaya (Bagian II: Jaringan Asia). Jakarta: PT. Gramedia Pustaka 
Orang Khmer di Jawa pada Masa Hindu-Buddha (Abad ke-9--15 M): Eksistensinya Dipandang dari Teori Diaspora- Muhamad

Alnoza (1-14)

Doi: $10.24832 / n w . v 15 i 1.453$

dan EFEO.

McHale, Shawn. 2013. "Ethnicity, Violence, and Khmer-Vietnamese Relations: The Significance of the Lower Mekong Delta, 1757-1954." Journal of Asian Studies 72 (2): 367-90. https://doi.org/10.1017/S0021911813000016.

Munandar, Agus Aris. 2014. "Konsep Devaraja Di Asia Tenggara Pada Masa Hindu-Buddha." HIm 97-119 dalam Mitra Satata: Kajian Asia Tenggara Kuna. Jakarta: Wedatama Widyasastra.

Munandar, Agus Aris. 2017. "Kerajaan Tarumanagara: Abad Ke-4-7 Masehi." HIm 67-98 dalam Kaladesa: Awal Sejarah Nusantara, editor A.A. Munandar. Jakarta: Wedatama Widyasastra.

Munandar, Agus Aris. 2018. "Seni Rupa Masa Majapahit: Data Arkeologis." HIm 145-178 dalam Wilwatikta Prana: Kajian Arkeologi-Sejarah Zaman Majapahit.

Munandar, Agus Aris. 2020. "Majapahit and the Contemporary Kingdoms: Interactions and Views." Berkala Arkeologi 40 (1): 1-22. https://doi.org/10.30883/jba.v40i1.522.

Nufus, Asri Hayati. 2018. "Orang-orang Asing di Jawa: Berdasarkan Data Prasasti Abad Ke-11-15 Masehi." Universitas Indonesia.

Pigeaud, Theodore G. 1960. The Nāgarakrtâgama by Rakawi Prapanca of Majapahit, 1365 AD. The Hague: Martinus Nijhoff.

Poesponegoro, Marwati Djoened, dan Nugroho Notosusanto. 2010. Sejarah Nasional Indonesia Jilid II: Zaman Kuno. Jakarta: Balai Pustaka.

Prihatmoko, Hedwi. 2014. "Transportasi Air dalam Perdagangan pada Masa Jawa Kuno di Jawa Timur." Forum Arkeologi 27 (3): 155-74.

Proyek Pengembangan Museum Nasional. 1986. Prasasti Koleksi Museum Nasional Jilid I. Jakarta: Museum Nasional Jakarta.

Rahardjo, Supratikno. 1994. "Hubungan Ekonomi dan Politik Antara Pusat dan Pinggiran: Kasus Tuban pada Masa Pra-Islam." Depok: Universitas Indonesia.

Ras, J.J. 2001. "Sacral Kingship In Java." HIm 373-388 dalam Fruit of Inspiration: Studies in Honour of J.G. de Casparis. Groningen: Egbert Forsten.

Ratnawati, Lien Dwiari. 1995. "Catatan Tentang Adanya 'Orang Asing' pada Masa Jawa Kuno Menurut Data Prasasti." HIm 18-23 dalam Analisis Hasil Penelitian Arkeologi, Analisis Sumber Tertulis Masa Klasik. Jakarta: Pusat Penelitian Arkeologi Nasional.

Safran, William. 1991. "Diasporas in Modern Societies: Myths of Homeland and Return." Diaspora 1 (1): 8399.

Sambodo, Goenawan A. 2018. "Prasasti Warungahan, sebuah Data Baru dari Masa Awal Majapahit." Amerta 36 (1): 23. https://doi.org/10.24832/amt.v36i1.438.

Santiko, Hariani. 2001. "The Religion of King Pūrṇawarman of Tarumanāgara." HIm. 432-334 dalam Fruit of Inspiration: Studies in Honour of J.G. de Casparis, editor Marijke J. Klokke and Karel R. van Kooij. Groningen: Egbert Forsten.

Schrieke, Bertram Johannes Otto. 2016. Kajian Historis Sosiologis Masyarakat Indonesia: Penguasa dan Kerajaan Jawa pada Masa Awal. Yogyakarta: Penerbit Ombak.

Smith, Monica L. 1999. "Indianization' from the Indian Oint of View: Trade and Cultural Contacts with Southeast Asia in the Early First Millennium C.E." Journal of the Economic and Social History of the Orient 42 (1): 1-26. https://doi.org/10.1163/1568520991445588.

Susanti, N. 2010. Airlangga: Biografi Raja Pembaharu Jawa Abad XI. Depok: Komunitas Bambu.

Susanti, Ninie. 2017. "Airlangga: His Relations To Kings in South and South-East Asia." Paradigma, Jurnal Kajian Budaya 4 (1): 1. https://doi.org/10.17510/paradigma.v4i1.155.

Tunon, Max, dan Khleang Rim. 2013. "Cross-Border Labour Migration in Cambodia: Considerations for the National Employment Policy."HIm 1-20 dalam Asia-Pasific Decent Work Decade. Bangkok: International Labor Organization.

Vickery, Michael. 1998. Society, Economics, and Politics in Pre-Angkor Cambodia: The 7th-8th Centuries. Tokyo: The Centre for East Asian Cultural Studies for Unesco, The Tokyo Bunko. 